\title{
PENINGKATAN HASIL BELAJAR MENULIS PUISI MELALUI MEDIA GAMBAR BERSERI SISWA KELAS VIII-1 SMP NEGERI 17 AMBON
}

\section{LEARNING OUTCOMES IMPROVEMENT IN WRITING POETRY THROUGH THE SERIAL IMAGE MEDIA IN STUDENTS CLASS VIII-1 SMP NEGERI 17 AMBON}

\author{
Everhard Markiano Solissa ${ }^{1}{ }^{*}$, Lesly Chriselya Wattimury ${ }^{2}$ \\ Pendidikan Bahasa dan Sastra Indonesia, FKIP Universitas Pattimura, Ambon, \\ Indonesia ${ }^{1,2}$ \\ everhard.solissa@fkip.unpatti.ac.id ${ }^{1}$, leslycwattimury@ gmail.com ${ }^{2}$ \\ *penulis korespondensi
}

\begin{tabular}{ll}
\hline Info Artikel & ABSTRAK \\
\hline Sejarah artikel: & Tujuan penelitian ini adalah meningkatkan kemampuan menulis puisi siswa \\
Diterima: & kelas VIII-1 SMP Negeri 17 Ambon. Data penelitian ini berupa hasil tes \\
4 Mei 2020 & menulis puisi yang diambil dari setiap siklus. Sampel berjumlah 25 siswa. \\
Direvisi: & Data tes dianalisis menggunakan rumus, yakni nilai siswa diperoleh dari \\
19 Juni 2020 & hasil bagi jumlah skor yang diperoleh siswa dengan skor ideal. Hasil tes \\
Disetujui: & siswa kemudian dikualifikasi sesuai kriteria yang telah ditentukan. Hasil \\
11 Juli 2020 & penelitian menunjukkan bahwa terjadi peningkatan hasil belajar menulis \\
& puisi siswa kelas VIII-1 SMP Negeri 17 Ambon dengan menggunakan \\
Kata kunci: & media gambar berseri. Hal itu terlihat dari jumlah siswa yang mencapai \\
Media Gambar Berseri, & KKM pada siklus pertama yakni 3 orang dengan nilai rata-rata semua \\
Peningkatan Hasil & siswa 51,70 menjadi 19 orang pada siklus kedua dengan nilai rata-rata \\
Belajar, Menulis Puisi, & semua siswa 75.
\end{tabular}

Penelitian Tindakan

Kelas

\begin{tabular}{|c|c|}
\hline Article Info & ABSTRACT \\
\hline $\begin{array}{l}\text { Article history: } \\
\text { Received: } \\
4 \text { May } 2020 \\
\text { Revised: } \\
\text { 19 June } 2020 \\
\text { Accepted: } \\
11 \text { July } 2020 \\
\text { Keyword: } \\
\text { Serial Image Media, } \\
\text { Learning Outcomes }\end{array}$ & $\begin{array}{l}\text { The aims of this research is to improve the ability to write poetry for VIII- } 1 \\
\text { grade students at SMP Negeri } 17 \text { Ambon. The data of this research are in } \\
\text { the form of poetry writing test results taken from each cycle. The sample } \\
\text { consisted of } 25 \text { students. Test data were analyzed using a formula that is the } \\
\text { student scores obtained from the results for the total score obtained by } \\
\text { students with an ideal score. Student test results are then qualified according } \\
\text { to predetermined criteria. The results showed that there was an increase in } \\
\text { the learning outcomes of writing poetry for VIII- } 1 \text { grade students of SMP } \\
\text { Negeri } 17 \text { Ambon by using serial media. This can be seen from the number } \\
\text { of students who reached the KKM in the first cycle namely } 3 \text { people with } \\
\text { an average value of all students } 51.70 \text {. It becomes } 19 \text { people in the second } \\
\text { cycle with an average value of all students } 75 \text {. }\end{array}$ \\
\hline
\end{tabular}

Improvement, Writing

Poetry, Classroom

Action Research 


\section{PENDAHULUAN}

Pendidikan merupakan upaya yang dilakukan untuk membudayakan manusia. Hal itu menunjukkan bahwa pemerintah konsisten untuk meningkatkan kualitas pendidikan dari tingkat dasar hingga perguruan tinggi. Pada tingkat sekolah dasar sampai sekolah menengah atas, pemerintah mulai aktif dalam pemberian bekal, penyuluhan, rapat, dan sebagainya.

Ada empat aspek keterampilan berbahasa, yaitu menyimak, berbicara, membaca dan menulis. Menulis memiliki peranan penting karena menulis adalah bagian dari komunikasi secara tertulis yang digunakan untuk menyampaikan gagasan atau ide kepada orang lain. Menulis berhubungan erat dengan keterampilan berbicara (bersifat produktif) maupun keterampilan membaca dan menyimak (bersifat reseptif) serta pemahaman kosa kata, diksi, dan keefektifan kalimat.

Hasil observasi di kelas VIII-1 SMP Negeri 17 Ambon ditemukan beberapa permasalahan dalam kegiatan pembelajaran. Pertama, semangat untuk belajar sangat rendah karena, banyak siswa yang melakukan aktivitas lain ketika proses pembelajaran. Kedua, referensi yang dipakai guru dan siswa belum memadai karena hanya terfokus pada buku paket saja. Sedangkan perkembangan zaman semakin maju, guru dan siswa juga harus mencari materi bukan hanya di buku paket namun di internet juga bisa. Ketiga, metode pembelajaran yang digunakan guru hanya berupa ceramah, Hal itu yang membuat siswa tidak termotivasi dalam mengikuti pelajaran.

Berdasarkan kenyataan tersebut maka penelitian dilakukan dengan tujuan meningkatkan hasil belajar siswa dalam menulis puisi. Media yakni gambar berseri. Melalui media pembelajaran ini siswa diberi kesempatan untuk berpartisipasi dan terlibat aktif dalam proses pembelajaran. Dengan menyajikan gambar yang menarik kepada siswa akan menumbuhkan sikap positif dan minat siswa terhadap pembelajaran. Hal ini bermuara pada peningkatan hasil belajar siswa.

Menulis adalah proses menuangkan pikiran dalam bentuk kata-kata yang disampaikan secara tidak langsung. Tarigan menyatakan bahwa kegiatan menulis merupakan suatu proses mengurutkan tanda atau lambang bahasa berupa tulisan yang dapat dimengerti pembaca (1994:21)

Menurut Semi (1990:11) ketika kita menulis sesuatu, kita harus mempunyai ide tentangnya karena suatu karangan harus tunduk kepada ide pokok dan mengekspresikan ide itu. Akhadiah (1997:13) menyatakan bahwa menulis merupakan suatu kegiatan penyampaian gagasan dengan tulisan. Karena menulis sulit, kegiatan menulis perlu dibimbing guru.

Tarigan (1994:24-25) menyatakan bahwa pada hakikatnya menulis bertujuan untuk menugaskan, menyenangkan, meyakinkan, menginformasikan, memperkenalkan diri, kreatif, dan memecahkan masalah.

Menurut Akhadiah, (1997:1-2) pada hakikatnya menulis berguna untuk menggali bakat dalam diri yang berhubungan dengan masalah yang ditulis, mengembangkan ide yang akan disampaikan, menambah cakrawala berpikir dalam bentuk teori, memperjelas masalah melalui kegiatan menulis, menilai secara objektif, memecahkan masalah secara kongkrit, sebagai motivator dan melatih pribadi untuk belajar lebih baik. 
Menulis merupakan salah satu instrumen yang cocok dalam belajar sebab akan melatih siswa dalam mengolah pikiran (Enre, 1988:6). Sementara Tarigan menyatakan bahwa menulis sebagai sarana komunikasi secara tak langsung sebab penulis dan pembaca tidak bertemu muka secara langsung (1994: 3).

Menurut Waluyo berpendapat bahwa (1987:25) puisi merupakan karya sastra yang mengekspresikan suasana batin seseorang dengan memanfaatkan bahasa sebagai sarananya.

Puisi oleh Pradopo (2014: 328) disebut sebagai ucapan yang mengaktualisasikan pengalaman panca indera.

Puisi merupakan hasil ungkapan kembali semua kejadian atau peristiwa dalam kehidupan manusia (Suharianto, 1981: 12). Menurut Nurgiantoro puisi merupakan salah satu jenis sastra yang mengutamakan segi kebahasaan. Hal itu menunjukkan bahwa diksi, isi, pengimajian, dan kata konkret menjadi hal yang harus diperhatikan oleh penulis.

Menurut Sudjana dan Ahmad Riva'i (2009: 56), media gambar dibedakan atas media gambar tunggal dan media gambar berseri.

Kegunaan gambar berseri yakni menciptakan suasana yang menarik dalam menyampaikan maksud tertentu dan sebagai perantara kepada siswa dalam mengungkapkan peristiwa seusai tema gambar berseri yang diperlihatkan. Gambar tersebut harus berurutan dengan diberi nomor urut agar mudah dipahami (Soeparno, 1988: 18).

Sadiman (2002: 29) menyatakan bahwa gambar berseri merupakan media yang sering digunakan, dan dapat dipahami dimana saja. Gambar berseri merupakan urutan gambar yang mengaktualisasikan ide dan gagasan tertentu.

\section{METODE}

Penelitian ini merupakan penelitian tindakan kelas bertujuan meningkatkan hasil siswa terutama menulis puisi. Sampel penelitian ini sebanyak 25 orang yang merupakan kelas yang memiliki nilai ujian blok terendah yakni $\leq 65 \%$ dari kelas lainnya. Instrumen penelitian yang digunakan dalam penelitian ini adalah lembar observasi, soal tes, angket, dan lembar kerja siswa (LKS). Pengumpulan data dilakukan melalui teknik observasi, angket, dan tes. Data tes sebagai data utama dianalisis dengan menggunakan rumus:

$$
\text { Nilai }=\frac{\text { Skor Perolehan }}{\text { Skor Maksimum }} \times 100
$$

(BNSP, 2007: 17)

Arikunto (2008: 37) menyatakan bahwa guru dapat menentukan nilai akhir siwa dengan caranya tersendiri dengan berpatokan pada pedoman penilaian yang digunakan di sekolahnya.

\section{HASIL DAN PEMBAHASAN}

Hasil penelitian ini dideskripsikan sebagai berikut.

\section{Pembelajaran Siklus I}

Langkah pertama yang dilakukan adalah memberikan kuesioner kepada siswa untuk diisi. 


\section{Siklus I Pertemuan Pertama}

Tabel 2 Hasil Angket Menulis Puisi Siswa Kelas VIII-1 SMP Negeri 17 Ambon

\begin{tabular}{|l|l|c|c|}
\hline \multirow{2}{*}{ No } & \multicolumn{1}{|c|}{ Pertanyaan } & \multicolumn{2}{|c|}{ Jawaban } \\
\cline { 2 - 4 } & & Ya & Tidak \\
\hline 1 & Apakah Anda senang belajar Bahasa Indonesia? & 24 & 1 \\
\hline 2 & Apakah materi yang disampaikan guru menarik? & 23 & 2 \\
\hline 3 & Apakah Anda senang dalam menulis puisi? & 11 & 14 \\
\hline 4 & Pernakah Anda menulis puisi? & 11 & 14 \\
\hline 5 & Apakah Anda senang jika diberi tugas untuk menulis puisi? & 16 & 9 \\
\hline 6 & Apakah saat menulis puisi Anda mengalami kesulitan? & 16 & 9 \\
\hline 7 & $\begin{array}{l}\text { Pernakah guru menggunakan media pembelajaran saat } \\
\text { menulis puisi? }\end{array}$ & 18 & 7 \\
\hline 8 & Apakah media yang digunakan guru selalu bervariasi? & 21 & 4 \\
\hline 9 & Apakah Anda pernah mendengar media gambar berseri? & 12 & 13 \\
\hline 10 & $\begin{array}{l}\text { Apakah Anda senang ketika belajar menggunakan media } \\
\text { gambar berseri? }\end{array}$ & 16 & 9 \\
\hline
\end{tabular}

Hasil angket pada tabel 2 dihitung sebagai berikut:

$$
\frac{24+23+11+11+16+9+18+21+12+16}{250}=64,4
$$

Hasil angket menunjukkan bahwa minat siswa kelas VIII-1 masih dilihat dari nilai rata-rata siswa yaitu rendah dalam menulis puisi. Hal itu 64,4. Hasil tersebut masih rendah sebab belum mencapai hasil yang diharapkan.

\section{Siklus I Pertemuan Kedua}

Tabel 3 Nilai Menulis Puisi Siswa Kelas VIII-1 SMP Negeri 17 Ambon

\begin{tabular}{|l|c|c|c|c|c|c|c|}
\hline \multirow{2}{*}{$\begin{array}{c}\text { Kode } \\
\text { Siswa }\end{array}$} & $\begin{array}{c}\text { Diksi } \\
(1)\end{array}$ & $\begin{array}{c}\text { Isi } \\
(2)\end{array}$ & $\begin{array}{c}\text { Pengimajian } \\
(3)\end{array}$ & $\begin{array}{c}\text { Kata } \\
\text { Konkret } \\
(4)\end{array}$ & Skor & Nilai & KKM \\
\hline S1 & 3 & 2 & 3 & 3 & 11 & 91.7 & Tuntas \\
\hline S2 & 1 & 2 & 1 & 1 & 5 & 41.7 & \\
\hline S3 & 1 & 2 & 1 & 1 & 5 & 41.7 & \\
\hline S4 & 1 & 2 & 3 & 1 & 7 & 58.3 & \\
\hline S5 & 1 & 2 & 1 & 1 & 5 & 41.7 & \\
\hline S6 & 1 & 2 & 1 & 1 & 5 & 41.7 & \\
\hline S7 & 1 & 2 & 1 & 1 & 5 & 41.7 & \\
\hline S8 & 1 & 2 & 1 & 1 & 5 & 41.7 & \\
\hline S9 & 2 & 2 & 2 & 2 & 8 & 66.7 & \\
\hline S10 & 3 & 3 & 3 & 2 & 11 & 91.7 & Tuntas \\
\hline
\end{tabular}




\begin{tabular}{|l|c|c|c|c|c|c|c|}
\hline \multirow{2}{*}{$\begin{array}{c}\text { Kode } \\
\text { Siswa }\end{array}$} & $\begin{array}{c}\text { Diksi } \\
(1)\end{array}$ & $\begin{array}{c}\text { Isi } \\
(2)\end{array}$ & $\begin{array}{c}\text { Pengimajian } \\
(3)\end{array}$ & $\begin{array}{c}\text { Kata } \\
\text { Konkret } \\
(4)\end{array}$ & Skor & Nilai & KKM \\
\hline S11 & 1 & 2 & 1 & 1 & 5 & 41.7 & \\
\hline S12 & 1 & 2 & 1 & 1 & 5 & 41.7 & \\
\hline S13 & 2 & 2 & 2 & 2 & 8 & 66.7 & \\
\hline S14 & 2 & 2 & 3 & 3 & 10 & 83.3 & Tuntas \\
\hline S15 & 1 & 2 & 1 & 1 & 5 & 41.7 & \\
\hline S16 & 2 & 2 & 2 & 2 & 8 & 66.7 & \\
\hline S17 & 1 & 2 & 1 & 1 & 5 & 41.7 & \\
\hline S18 & 1 & 2 & 1 & 1 & 5 & 41.7 & \\
\hline S19 & 1 & 2 & 1 & 1 & 5 & 41.7 & \\
\hline S20 & 1 & 2 & 1 & 1 & 5 & 41.7 & \\
\hline S21 & 1 & 2 & 1 & 1 & 5 & 41.7 & \\
\hline S22 & 1 & 2 & 1 & 1 & 5 & 41.7 & \\
\hline S23 & 1 & 2 & 2 & 2 & 7 & 58.3 & \\
\hline S24 & 1 & 2 & 1 & 1 & 5 & 41.7 & \\
\hline S25 & 1 & 2 & 1 & 1 & 5 & 41.7 & \\
\hline & & & & & & & \\
\hline
\end{tabular}

Tabel 3 menunjukkan bahwa siswa yang belum mencapai KKM (72) adalah 22 orang siswa sedangkan yang mencapai KKM (72) adalah 3 orang siswa. Siswa belum mampu menulis puisi dengan baik. Hal itu dapat dilihat dari nilai rata-rata pada siklus I yakni 51.70. Nilai rata-rata tersebut belum memuaskan sebab masih rendah dan belum mencapai hasil yang diharapkan.

\section{1) Data Kesulitan Siswa}

Tabel 4 Data Kesulitan Menulis Puisi

Siswa Kelas VIII-1 SMP Negeri 17 Ambon

\begin{tabular}{|c|c|}
\hline Kode Siswa & Kesulitan Siswa \\
\hline S1 & - \\
\hline S2 & aspek 1, 3 dan 4 \\
\hline S3 & aspek 1, 3 dan 4 \\
\hline S4 & aspek 1 dan 4 \\
\hline S5 & aspek 1, 3 dan 4 \\
\hline S6 & aspek 1, 3 dan 4 \\
\hline S7 & aspek 1, 3 dan 4 \\
\hline S8 & aspek 1, 3 dan 4 \\
\hline S9 & aspek 1, 2, 3 dan 4 \\
\hline S10 & - \\
\hline S11 & aspek 1, 3 dan 4 \\
\hline S12 & aspek 1, 3 dan 4 \\
\hline
\end{tabular}




\begin{tabular}{|c|c|}
\hline S13 & aspek 1, 2, 3 dan 4 \\
\hline S14 & - \\
\hline S15 & aspek 1, 3 dan 4 \\
\hline S16 & aspek 1, 2, 3 dan 4 \\
\hline S17 18 & aspek 1, 3 dan 4 \\
\hline S19 & aspek 1, 3 dan 4 \\
\hline S20 & aspek 1, 3 dan 4 \\
\hline S21 & aspek 1, 3 dan 4 \\
\hline S22 & aspek 1, 3 dan 4 \\
\hline S23 & aspek 1, 3 dan 4 \\
\hline S24 & aspek 1 \\
\hline S25 & aspek 1, 3 dan 4 \\
\hline & aspek 1, 3 dan 4 \\
\hline
\end{tabular}

Hasil tersebut menunjukkan bahwa 22 siswa belum dapat menentukan diksi (aspek 1) dengan tepat, 21 siswa siswa belum dapat menentukan kata konkret (aspek 4), 20 siswa belum dapat menentukan pengimajian (aspek 3), dan 3 siswa belum dapat menentukan isi puisi (aspek 2) dengan tepat. Dengan demikian, dapat disimpulkan bahwa diksi, kata konkret dan pengimajian merupakan aspek yang masih sulit dipahami siswa.

\section{Pembelajaran Siklus II}

Pembelajaran menulis puisi dengan menggunakan media pembelajaran gambar berseri pada siklus II dilaksanakan dalam 2 kali pertemuan. Berikut ini adalah hasil PTK yang dilakukan pada siswa kelas VIII-1 SMP Negeri 17 Ambon.

\section{Siklus II Pertemuan Pertama}

Tabel 5 Hasil Angket Menulis Puisi Siswa Kelas VIII-1 SMP Negeri 17 Ambon

\begin{tabular}{|l|l|c|c|}
\hline \multirow{2}{*}{ No } & \multicolumn{1}{|c|}{ Pertanyaan } & \multicolumn{3}{|c|}{ Jawaban } \\
\cline { 2 - 4 } & \multicolumn{1}{|c|}{ Ya } & Tidak \\
\hline 1 & Apakah Anda senang belajar Bahasa Indonesia? & 25 & - \\
\hline 2 & Apakah materi yang disampaikan guru menari? & 24 & 1 \\
\hline 3 & Apakah Anda senang dalam menulis puisi? & 17 & 8 \\
\hline 4 & Pernakah Anda menulis puisi? & 22 & 3 \\
\hline 5 & Apakah Anda senang jika diberi tugas untuk menulis puisi? & 19 & 6 \\
\hline 6 & Apakah saat menulis puisi Anda mengalami kesulitan? & 13 & 12 \\
\hline 7 & $\begin{array}{l}\text { Pernakah guru menggunakan media pembelajaran saat } \\
\text { menulis puisi? }\end{array}$ & 18 & 7 \\
\hline 8 & Apakah media yang digunakan guru selalu bervariasi? & 19 & 6 \\
\hline 9 & Apakah Anda pernah mendengar media gambar berseri? & 17 & 8 \\
\hline 10 & $\begin{array}{l}\text { Apakah Anda senang ketika belajar menggunakan media } \\
\text { gambar berseri? }\end{array}$ & 19 & 6 \\
\hline
\end{tabular}


Hasil angket pada tabel 5 dihitung sebagai berikut:

$$
\frac{25+24+17+22+19+12+18+19+17+19}{250}=76,8
$$

Hasil angket pada siklus II pertemuan ke-1 menunjukkan bahwa siswa kelas VIII-1 SMP Negeri 17 Ambon telah termotivasi untuk menulis puisi. Hal itu dapat dilihat pada nilai rata-rata yakni 76,8 .

\section{Siklus II Pertemuan Kedua}

Tabel 6 Nilai Menulis Puisi Siswa Kelas VIII-1 SMP Negeri 17 Ambon

\begin{tabular}{|l|c|c|c|c|c|l|l|}
\hline \multirow{2}{*}{$\begin{array}{c}\text { Kode } \\
\text { Siswa }\end{array}$} & $\begin{array}{c}\text { Diksi } \\
(1)\end{array}$ & $\begin{array}{c}\text { Isi } \\
(2)\end{array}$ & $\begin{array}{c}\text { Pengimajian } \\
(3)\end{array}$ & $\begin{array}{c}\text { Kata } \\
\text { Konkret } \\
(4)\end{array}$ & Skor & Nilai & KKM \\
\hline S1 & 2 & 3 & 2 & 2 & 9 & 75 & Tuntas \\
\hline S2 & 1 & 2 & 1 & 1 & 5 & 41.7 & \\
\hline S3 & 2 & 3 & 2 & 2 & 9 & 75 & Tuntas \\
\hline S4 & 1 & 2 & 1 & 1 & 5 & 41.7 & \\
\hline S5 & 2 & 3 & 2 & 2 & 9 & 75 & Tuntas \\
\hline S6 & 2 & 2 & 2 & 2 & 8 & 66.7 & \\
\hline S7 & 3 & 3 & 2 & 2 & 10 & 83.3 & Tuntas \\
\hline S8 & 3 & 3 & 2 & 2 & 10 & 83.3 & Tuntas \\
\hline S9 & 1 & 2 & 1 & 1 & 5 & 41.7 & \\
\hline S10 & 3 & 3 & 2 & 2 & 10 & 83.3 & Tuntas \\
\hline S11 & 3 & 3 & 2 & 2 & 10 & 83.3 & Tuntas \\
\hline S12 & 2 & 3 & 2 & 2 & 9 & 75 & Tuntas \\
\hline S13 & 2 & 2 & 2 & 2 & 8 & 66.7 & \\
\hline S14 & 3 & 3 & 3 & 2 & 11 & 91.7 & Tuntas \\
\hline S15 & 3 & 3 & 2 & 2 & 10 & 83.3 & Tuntas \\
\hline S16 & 3 & 3 & 2 & 3 & 11 & 91.7 & Tuntas \\
\hline S17 & 1 & 2 & 1 & 1 & 5 & 41.7 & \\
\hline S18 & 3 & 3 & 2 & 2 & 10 & 83.3 & Tuntas \\
\hline S19 & 3 & 2 & 3 & 3 & 11 & 91.7 & Tuntas \\
\hline S20 & 3 & 3 & 2 & 2 & 10 & 83.3 & Tuntas \\
\hline S21 & 2 & 3 & 2 & 2 & 9 & 75 & Tuntas \\
\hline S22 & 2 & 2 & 3 & 3 & 10 & 83.3 & Tuntas \\
\hline S23 & 3 & 3 & 2 & 3 & 11 & 91.7 & Tuntas \\
\hline S24 & 2 & 3 & 3 & 2 & 10 & 83.3 & Tuntas \\
\hline S25 & 3 & 3 & 2 & 2 & 10 & 83.3 & Tuntas \\
\hline & & & & & rata-rata & 75 & \\
\hline
\end{tabular}


Tabel 6 menunjukkan bahwa 19 dari 25 siswa telah mencapai KKM 72. Kemampuan menulis puisi terkait dengan diksi, kesesuaian isi dengan tema, pengimajian, dan kata konkret pada siklus II sudah mencapai nilai yang diharapkan, karena nilai rerata siswa adalah 75 .

\section{1) Data Kesulitan Siswa}

Tabel 7 Data Kesulitan Menulis Puisi

Siswa Kelas VIII-1 SMP Negeri 17 Ambon

\begin{tabular}{|c|l|}
\hline $\begin{array}{c}\text { Kode } \\
\text { Siswa }\end{array}$ & \multicolumn{1}{|c|}{ Kesulitan Siswa } \\
\hline S1 & - \\
\hline S2 & aspek 1, 3 dan 4 \\
\hline S3 & - \\
\hline S4 & aspek 1, 3 dan 4 \\
\hline S5 & - \\
\hline S6 & aspek 1, 3 dan 4 \\
\hline S7 & - \\
\hline S8 & - \\
\hline S9 & aspek 1, 3 dan 4 \\
\hline S10 & - \\
\hline S11 & - \\
\hline S12 & - \\
\hline S13 & aspek 1, 2, 3 dan 4 \\
\hline S14 & - \\
\hline S15 & - \\
\hline S16 & - \\
\hline S17 & aspek 1, 3 dan 4 \\
\hline S18 & - \\
\hline S19 & - \\
\hline S20 & - \\
\hline S21 & - \\
\hline S22 & - \\
\hline S23 & - \\
\hline S24 & - \\
\hline S25 & - \\
\hline & \\
\hline
\end{tabular}

Tabel 7 menunjukkan bahwa terjadi pengurangan kesulitan siswa dalam menentukan semua aspek, yakni aspek 1 (diksi) dari 22 siswa menjadi 6 siswa, aspek 4 (kata konkret) dari 21 siswa menjadi 6 siswa, aspek 3 (pengimajian) dari 20 siswa menjadi 6 siswa, dan aspek 2 (isi puisi) dari 3 siwa menjadi 1 siswa. 


\section{PENUTUP}

Berdasarkan hasil penelitian dan pembahasan disimpulkan bahwa hasil angket pada siklus I pertemuan pertama, siswa belum berminat terhadap pelajaran bahasa Indonesia. Hal itu dibuktikan dengan hasil perhitungan angket, di mana rata-rata nilai siswa yang masih rendah yakni 64,8 .

Hasil tes menulis puisi pada siswa kelas VIII-1 SMP Negeri 17 Ambon masih rendah. Hal itu dilihat pada hasil tes menulis puisi, di mana hanya $12 \%$ dari jumlah siswa yang nilainya mencapai KKM 72.

Hasil angket pada siklus II sudah menunjukan peningkatan sebab nilai rata-rata siswa telah mencapai 76,8 yang sesuai dengan harapan peneliti.

Hasil tes keterampilan menulis pada siswa kelas VIII-1 SMP Negeri 17 Ambon sudah menunjukan adanya peningkatan. Hal itu dilihat dari hasil menulis puisi, di mana $76 \%$ siswa yang sudah mencapai KKM 72.

\section{DAFTAR PUSTAKA}

Akhadiah, Sabarti (1997). Menulis. Jakarta: Departemen Pendidikan dan Kebudayaan.

Arikunto,Suharsimi (2008). Penelitian Tindakan Kelas. Jakarta: Bumi Aksara.

BSNP, (2007). Model Penilaian Kelas SMP/MTs. Jakarta: Direktorat Jenderal Pendidikan Dasar dan
Menengah

Departemen

Pendidikan Nasional.

Enre, Fachrudin Ambo (1988). DasarDasar Keterampilan Menulis. Jakarta: Depdikbud.

Nurgiantoro, Burhan (2005). Teori Pengkajian Fiksi. Yogyakarta: Gadjah Mada University Press.

Pradopo, Rachmad Djoko (2014). Pengkajian Puisi. Yogyakarta: Gajah Mada University Press.

Sadiman, S. Arif (2002). Media Pendidikan. Jakarta: PT. Raja Grafindo Persada.

Semi, M. Atar (1990). Menulis Efektif. Jakarta: Angkasa Raya.

Soeparno. (1988). Media Pengajaran Bahasa. Klaten: Intan Pariwara.

Sudjana dan Ahmad Riva'i. (2009). Media Pembelajaran. Bandung: Sinar Baru Algensindo.

Suharianto (1981). Pengantar Apresiasi Puisi. Jakarta: Gramedia.

Tarigan, H. G (1994). Menulis Sebagai Suatu Keterampilan Berbahasa. Bandung: Angkasa

Waluyo, Herman J (1987). Teori dan Apresiasi Puisi. Jakarta: Erlangga. 